\title{
Development of Disaster Mitigation Learning Structures
}

\author{
I Wayan Gunada ${ }^{1}$, Syahrial Ayub $^{1 *}$, Aris Doyan ${ }^{1}$, Muhammad Taufik $^{1}, \operatorname{Kosim}^{1}$ \\ ${ }^{1}$ Program Studi Pendidikan Fisika, Fakultas Keguruan dan Ilmu Pendidikan Universitas Mataram, Mataram, Indonesia
}

DOI: $10.29303 /$ jppipa.v6i1.324

Citation: Gunada, I. W., Ayub, S., Doyan, A., Taufik, M., Kosim. 2020. Development of Disaster Mitigation Learning Structures. Jurnal Penelitian Pendidikan IPA (JPPIPA). 6(1). pp. 69-74.

Article history

Received: May $31^{\text {th }} 2019$

Revised: November $27^{\text {th }} 2019$

Accepted: December $22^{\text {th }} 2019$

*Coresponding Author: Syahrial Ayub: Program Studi Pendidikan Fisika, Fakultas Keguruan dan Ilmu Pendidikan Universitas

Mataram, Mataram, Indonesia.

Email: syahrial.ayub@gmail.com

\begin{abstract}
This research aims to determine the structure of disaster mitigation learning in elementary schools. It is Research and Development also known as RnD study. This research gives a real-life example of how a teacher can teach and embed the awareness about natural disasters in an uncomplicated and fun way, by using the disaster mitigation model of teaching. The study results in one design of a disaster mitigation model of teaching and a teaching structure implementing a scientific approach on disaster mitigation. This research is based on the development and real-life experience of the researcher team in teaching and doing observation and research on the headmaster, teachers, and the students of Mataram 6 elementary school. It is the pilot project of this research, which in return will be implemented in other schools in the urban, coastal area, as well as the mountainous area in Lombok Island. The result shows that the headmaster and the teachers' response towards the disaster mitigation model of teaching had been really positive, with only $5 \%$ of the teachers claims that they are interested, whilst the other 95\% claim that the study is extremely interesting for them. The students were very enthusiastic and active during the learning process. Besides, the claim to have meaningful benefit from this mitigation learning. This thus indicated that this mitigation model of teaching and learning can be used as a guide or reference in embedding the awareness for natural disasters among the school community.
\end{abstract}

Keywords: Determination; disaster mitigation; elementry school; learning; structure

\section{Introduction}

As one of the islands in the Indonesia region, Lombok is prone to the occurance of earthquakes. In a fairly recent event, 4 major earthquakes stroke Lombok. The series of earthquakes occurred between July and August 2018, starting with a 6.4 SR earthquake on July 29th, and followed by 7, 6.2, and 7 SR earthquakes on August 5th, August 9th and August 19 th respectively. This was also worsened by the occurrence of no fewer than 2500 aftershocks. This occurence of earthquakes put huge impacts on the people of Lombok Island, especially those living in the coastal, mountainous, and urban areas. This is marked by the destruction of infrastructures and buildings in those affected areas, as well as the loss of hundreds of people's lives (Diposaptono, 2005). Preliminary study and observation show that the people's awareness towards earthquake and its mitigation is highly insufficient. An earthquake is a natural disaster with no way of predicting its occurrence (Syahrial,2019). It can occur while people are working, sleeping, playing, as well as while they are studying at school. Children are the most vulnerable group of people to be injured in an earthquake, along with teachers and other school's apparatus. This is why it is extremely important to equip them with the knowledge regarding the concept and the danger of earthquakes, early warning, school evacuation plan procedures, self rescue, and first aid procedure to be implemented to a victim. This is so that the effects and lost from the disaster can be minimalized. Furthermore, earthquake is only one example of a natural disaster that often strikes Indonesian. Other examples also include tsunami, landslide, draught, flood, storm, and volcanic eruption. 
Teaching something new to children surely needs a method that is exact, effective and fun (Djamarah, 2005). This research aims to develop a disaster mitigation model of learning for elementary school teachers and students in urban, coastal, and mountainous area of Rinjani in Lombok Island. By using the correct method, in both the teacher and the students' mind, there will be embedded an awareness towards natural disaster, as well as an implusive response to take the right action in case of an occuring natural disaster (UNDP, 1995). Besides, this correct method includes a complete guide of disaster mitigation learning structure for the teacher who will teach it. This disaster mitigation model of learning is developed by implementing one approach that is judged as able to make learning process effective, innovative, creative and fun. One of the approaches that is deemed to be suitable is scientific approach. Scientific approah makes use of discovery learning (Irawan, 1997). Discovery learning it self is a learning model which involves the students' full and maximum ability to look for and discover a thing, human, or event sistematically, critically, logically, and analitically so that the students themselves can formulate their findings confidently (Syahrial, 2011). Other than that, during the learning process, the teachers should have helped the students to actively look for a concept, a principle, and fact for themselves, and not only gives lecturer and controls the class (teacher oriented). This way, the students will be able to build their own knowledge.

The awareness towards natural disaster in the mind of students, teachers, and principals will survace from mitigation learning that will be held. Without this process, it is impossible for natural disaster awareness to be embedded in their mind, so that the main purpose to reach the society will be hard to achieve (Klinger, 1997). Apart from this mitigation learning process, the school society is also given the knowledge regarding (1) the signs of natural disaster (2) the impact of natural disaster (3) the risk and how to lower it (4) the state of being prepared and on the alert for the disaster, (5) the first aid kit, as well as the procedure for treating the victims. This way, it is hoped that the students, teachers, and principals will be able to understand about disaster and its mittigation well (Suprapto, 2002).

To answer the challenge, A teacher must teach their students about a natural disaster and its mitigation through Science Process Skills. Science Process Skill becomes the base of the scientific approach in the 2013 Curriculum. One of the many activities that can be applied by the teacher is practicing (Ramdhani, 2005). Through practicing, students will obtain real life experience regarding natural disaster and its mitigation. Here, it will be easier for the students to remember the concept of natural disaster if they see the disaster in person. What's more here is that the students will not only memorize the concept but will also understand it if it were to happen to themselves. Through practicing, the students could figured out the problem, as well as its answer. The problems discovered through the practices will be a potential source of learning for the students to learn more. The learning process that takes place will also have valuable scientific content. This is because the problem will be able to be solved through the practice instead of through theoritical lecture from the teacher. Through the practice, the students might also be trained to use simple, valid scientific methods such as those used by a scientist (Hamidah, 2018).

This writing is based on the research result, experience, and observation on the teaching and learning of disaster in the classroom using scientific approach with practice (Ivers, 2002). The intriguing problems found here are as follows 1) How to teach about the concept of disaster using student-oriented mitigation learning model? 2) How does studentoriented mitifarion learning structure look like? 3) How does the students, teachers, and principal react to student-oriented mitigation learning?

\section{Method}

The disaster mitigation model of learning and the learning structure that was discovered is the result of research and development conducted by researcher team. In reality, this research has been conducted continually earlier, while researcher team was joining a project to enhance disaster awareness in primary school, a collaboration project between Indonesian and German called DAPS (Disaster Awareness in Primary School) from 2007 to 2013. The implementation of the model designed by researchers from many different places is evaluated and reflected on the next implementation, thus resulting in the current model of disaster mitigation learning (Ivers, 2002). Research and Development (also known as $\mathrm{RnD}$ ) is used to produce and test the effectivity of certain product. This research is done in 4 stages, namely deciding, designing, developing, and evaluating (Sugiyono, 2013). In the beginning of the research, to develop the learning model, brainstorming is done, along with content analysis and literature review. One major thing that was decided at this stage is the concept of disaster that will be used as a model. During designing stage, the researcher designed a learning model with 3 stages, namely, introductory, core, and closing activities, which are all synchronized with the scientific approach (Hairunnisa, 2017). During developing stage, the researcher kept perfecting the deficiencies of the 
models designed. Based on the continuous evaluation, it is hoped that the best model to give real life examples of simple disaster mitigation learning based on a scientific approach can be obtained.

\section{Result and Discussion}

Scientific Approach recommends 3 types of learnings, namely (1) Discovery Learning, (2) Problem Based Learning, and (3) Project Based Learning. The different from the lecturing method, the main focus of Discovery learning methods is the students' independent activity (Huda, 2013). The material is indeed chosen and prepared by the teacher, but the students independently discuss one specific problem (or the teacher might throw a certain question) at the beginning of the lesson. The discussion and the activities are mostly decided by the student themselves, both during the learning process in the classroom or in groups.

This method has some superiorities, namely: 1) The development of the students' independent activities and independency. 2) The stimulation for the students' ability to plan, organize, and execute an activity. 3) The development of responsibilities towards a work. 4) The introduction to methods of working and thinking in research area.

Discovery learning model is proven to have positive impact towards the students' learning outcome (Subrata, 2001). One major success from this century's learning practice and theory is that the students are now considered as a thoughtful partner who can act on their own, and are not only expected to master and memorize the knowledge that they don't understand or that are not taught/ explained objectively. This learning method allows the students themselves to experience the feeling of discovering new connections and how to reach knowledge through independent measure.

Table 1: Problem Solving Teaching Structure

\begin{tabular}{|c|c|c|}
\hline No & Teaching stages & To Aim \\
\hline 1 & Motivation & $\begin{array}{l}\text { To build the students' interest } \\
\text { and curiosity towards the } \\
\text { material that will be taught }\end{array}$ \\
\hline 2 & Problem Dechiper & $\begin{array}{l}\text { To formulate a scientific } \\
\text { question }\end{array}$ \\
\hline 3 & Opinion making & To formulate hypothesis \\
\hline 4 & $\begin{array}{l}\text { Planning and } \\
\text { constructing }\end{array}$ & $\begin{array}{l}\text { To prepare the equipment to } \\
\text { be used in practice }\end{array}$ \\
\hline 5 & Practice & $\begin{array}{l}\text { The embodiment of a natural } \\
\text { reaction }\end{array}$ \\
\hline 6 & Conclusion & $\begin{array}{l}\text { A conclusion of one problem } \\
\text { solving procesure }\end{array}$ \\
\hline 7 & Abstraction & Valid scientific result \\
\hline 8 & $\begin{array}{l}\text { Knowledge } \\
\text { consolidation } \\
\text { through }\end{array}$ & $\begin{array}{l}\text { Comprehensive knowledge } \\
\text { regarding a natural } \\
\text { symptoms/ disaster and the }\end{array}$ \\
\hline
\end{tabular}

\begin{tabular}{lll}
\hline No & Teaching stages & To Aim \\
\hline $\begin{array}{l}\text { application and } \\
\text { practice }\end{array}$ & integration of learning result \\
\hline
\end{tabular}

(Syahrial, 2019)

Problem Based Learning is about solving the learning material-related problem, and not about how teacher lectures about the learning Material. Problem based learning model with experiment methods from provides an authentic experience which will push or motivate the students to study actively (Ibrahim, 2000).

The mitigation model of learning is developed based on the approaches explained previously. There are 3 main stages of this disaster mitigation learning, namely: (1) Introductory activity, (2) Core Activity, and (3) Reinforcement activity. Each activity in these main stages will have their own aims and purpose.

\section{Introductory Activity}

The introductory activities in this disaster mitigation learning aims to motivate the students so that they are interested in following the learning material of disaster mitigation learning that will take place. This is a very important thing to do to bring out students' desire to learn, especially regarding disaster mitigation. Some alternatives of activities that can be used by the teacher to motivate the students are as follows: (1) a demo using something that the teacher's bring (2) video playback (3) story telling (4) singing a song that is related to the material that will be taught (5) review/ continuing the previous unfinished lesson (6) observing/ discussing about the technical implementation in the surrounding environment (8) Collecting and discussing the students' initial knowledge, and (9) presenting a poster/ picture about natural disaster. The point of the introductory activities that the teacher designs are that the students will be able to find the problem that will be taught independently. By making sure that the problem is found by the student themselves, it is hoped that the students will be interested and motivated to follow the following stage of learning.

As an example, at the beginning of the lesson the teacher might tell a story such as follows:

One morning, in the island of Simeuleu--an Island located $176 \mathrm{~km}$ offshore Meulaboh City (NAD) children were playing together along the seashore, just as they used to do. They looked very happy. Among those children are Fachri and Hanafi, seriously indulged in playing soccer. They were accompanied by Aminah and Siti, their two bestfriends who were chatting on top of a big stone. Out of the sudden, the earth shook. "GREEEEK GREEEEK GREEEEEK!" Everybody panicked and fell down. "GREEEEK BRAK", coconuts and other stuffs also fell. "Earthquake! Earthquake! There's an 
earthquake!", said Fachri and Hanafi while falling down. "O Allah, Why is there an earthquake so early in the morning?" said another child while running towards the higher ground. "Allahu Akbar! Oh God Forgive us! Earthquake! Earthquake! Run!" A couple of minutes later, the earthquake stopped. Many houses were destroyed because they couldnt stand the vibration of the earthquake. Suddenly, someone said, "SMONG! This is terrible! Let's go Hanafi, he have to go to the hills! Quick! SMONG is a giant wave! A giant wave told by our ancestor throughout the years!" "A giant wave? I dont buy it! Where's the prove of that? Is there any sign of the SMONG?" Fachri said, while pointing at the seashore so that Hanafi looked at the seashore. (SMONG is the Semeuleu's word for Tsunami).

"Heeei! Where are you going, Hanafi! Come back!" yelled Fachri while bulging his eyes out to Hanafi. "No! Because the sea water is gone, I want to take those shells. You go first!" said Hanafi to Fachri while running towards the sea. "Hanafi! Come back! We have to run towards the hills as fast as possible! Be quick! I'll meet you there!" screamed Fachmi while running towards the hills, leaving Hanafi. "Wow. Such nice shells! Just like the one in...." Hanafi couldnt finish his words as he turned pale, "THE SEA..... ZAAAAZAAAAA," Just as sudden as the earthquake, there came a giant wave from the sea, which swallowed Hanafi and the whole village.It is hoped that from this story, the students will be eager to ask questions and at the end of this introductory activity can formulate the problems for disaster mitigation learning that will take place.

\section{Core Activities}

A problem that emerges at the end of introductory activities indicates that the teacher will soon continue the learning stage to core activities. The problem shall not be answered, but merely collected by the teacher (the giving of feedback is deemed better Table 2: Disaster Mitigation Learning Structure, Researcher's recommendation

\begin{tabular}{lll}
\hline Main Stage & Learning Stage & Alternatives of Activities Teacher can use \\
\hline Intro-ductory & Introduc-tion & - A demo using something that the teacher's bring \\
Activity & - Video playback \\
& - Story telling \\
& - Singing a song (related to the material that will be taught) \\
& - review/ continuing the previous unfinished lesson \\
& - observing/ discussing about the technical implementation in \\
& the surrounding environment \\
& - phenomenon presentation
\end{tabular}

Explore students' initial knowledge

Core Activity The formulation of questions/ problems regarding the topic, disaster mitigation

Activity here). Here, the teacher merely directs the student to answer this problem during core activities. During core activities of disaster mitigation learning, the teacher should pay attention to the phase before and during the disaster occur, as well as to the rescue process, and the phase after people reach safe zone and perform first aid procedure to the victims. Some alternatives of activities that can be chosen by the teachers are: (1) performing practice (2) game/ simulation (3) clasification/ grouping (4) checking evacuation map (5) checking first aid kit. During this process, the students are expected to actively particaipate and do as much observation as possible. It is then expected that the students will be able to draw a conclusion based on the students' explanation (guess-estimate-discuss) and thinking base. After the conclusion is drawn, the problem that emerges at the beginning will be answered automatically. The students themselves will realize and judge whether their answers at the beginning of core activities are correct or not. Thus here, the teacher will not judge the students' answer. This process is what makes disaster mitigation learning become fun, intriguing, and innovative.

\section{Reinforcement Activities}

In the reinforcement activities, there will some things that must be discussed by the teacher, namely: (1) implementing (related to the students' own surrounding environment), (2) answering questions, (3) making summary, and (4) giving homework. If we link this learning stages with scientific approach, we found out that the stages match perfectly. There are 6 stages of scientific approach, namely, (1) observing, (2) questioning (3) collecting information, (4) this result, the researcher team then figured out one disaster mitigation learning structure as follows: associating (5) inferring, (6) communicating. Based on
Collecting and discussing the students' initial knowledge

Formulating the questions or problems regarding the topic, disaster mitigation

- Performing practice

- Game/ simulation

- Classification/grouping 


\begin{tabular}{|c|c|c|}
\hline Main Stage & Learning Stage & Alternatives of Activities Teacher can use \\
\hline & & $\begin{array}{l}\text { - Checking evacuation map } \\
\text { - Checking first aid kit }\end{array}$ \\
\hline & Observation & Doing as much observation as possible \\
\hline & $\begin{array}{l}\text { The answer to the question } \\
\text { Problem solving }\end{array}$ & $\begin{array}{l}\text { - Students' explanation (guess-estimate-discuss) } \\
\text { - Thinking base } \\
\text { - Conclusion drawing }\end{array}$ \\
\hline & $\begin{array}{l}\text { The teacher's explanation (if } \\
\text { necessary) }\end{array}$ & \\
\hline & Re-inforcement activity & $\begin{array}{l}\text { Implementing (related to the students' own surrounding } \\
\text { environment) } \\
\text { Answering questions } \\
\text { Making summary } \\
\text { Giving homework }\end{array}$ \\
\hline
\end{tabular}

\section{Conclusion}

The implementation of discovery learning/ scientific approach on the structure of disaster mitigation learning is very suitable in natural disasterrelated lesson. It is proven that this way of learning causes the students to understand more about the concept of disaster that they learn. They are also more enthusiastic, and actively involved in the learning process. The same applies to the teacher, in that the method demands the teacher to have certain skills. For example, the teacher must be able to master the material, and to think logically as an actual scientist. The teacher should also have democratic and open mind, in addition to the ability to quickly renspond to other people's mind and the desire to always improve themselves. The belief that scientific approach limits teacher's creativity is thus proven to be false. This is because in reality, scientific approach provides teachers with more authority to optimalize their creativity and innovation.

\section{References}

Diposaptono, S. (2005). Tsunami Mitigation Technology. Republic of Indonesia Maritime and Fisheries Agency Tsunami Mitigation Training Material

Djamarah. (2005). Teachers and Students in Educative Interaction, A Psychological Theoretical Approach, Jakarta , Rineka Cipta.

Huda, M. (2013). Teaching and Learning Model Models of Methodical and Pragmatic Issues. Yogyakarta, Pustaka Pelajar

Hamidah, G., \& Taufik, M. (2018). Effect of Media Assisted Discovery Learning Model on Physics
Learning Outcomes of Class XI Students of SMA N 1 Kediri Academic Year 2017/2018. Jurnal Pendidikan Fisika dan Teknologi. 4(1). https://jurnalfkip.unram.ac.id/index.php/JPFT/ar ticle/view/519

Hairunnisyah, S., Gunawan., Indriaturrahmi., \& Fitri A. (2017). E-Assessment System Design on Physics Learning at LPTK. Jurnal Pendidikan Fisika dan Teknologi, 3(2). https://jurnalfkip.unram.ac.id/index.php/JPFT/ar $\underline{\text { ticle/view/422 }}$

Irawan, P. (1997). Learning Theory. PAU-PPAI. Jakarta: Universitas Terbuka.

Ivers, B. (2002). Multimedia Projects in Education Designing Producing and Assesing. New York: John Willey \& Sons.

Ibrahim. M. (2000). Problem Based Learning. Surabaya: University Press.

Klinger, W. (1997). Survey of Teaching Methods in Natural Sciences Erziehungswiss. Fakultat der Universtat: Erlangen-Nurnbe.

Ramdhani A. (2005). Optimization of Physics Learning with the Use of Science Kits at SMP N 6 Mataram. Mataram: Press Unram,.

Syahrial, A., Kosim., Gunada, I. W. 2019. Tsunami. Gunung Sari West Lombok 2019: Arga Puji.

Syahrial, A. (2011). Study of the Use of elementry school Science Kits in Mataram, Mataram 2011, Lembaga Penelitian Universitas Mataram

Suprapto S. (2002), Flood Disaster, Material for Disaster Power Training. Yogyakarta PSBA UGM.

Sugiyono. (2013). Qualitative Quantitative Research Methods and $R \& D$. Bandung: Alfabeta.

Subrata. (2001). Efforts to Improve the Quality of Learning Outcomes of Elementary Students through Science Learning with Process Skills. Laporan Penelitian STKIP Singaraja. 
UNDP. (1995). Introduction to Hazard, 2nd Edition.

Disaster M Management Training Programe,

Wisconsin 1995, University of Wisconsin, USA. 